\title{
Molecular Interactions of a Zinc(II) Macrocycle towards Carboxylate Ligands
}

\author{
Hanyoung Park, Ju Chang Kim, ${ }^{*}$ Alan J. Lough. ${ }^{\dagger}$ and Byung Min Lee ${ }^{*}$
}

\author{
Department of Chemistry, Pukyong National University, Busan 608-737, Korea. "E-mail. kimjc@pknu.ac.kr" \\ ${ }^{\dagger}$ Department of Chemistry, University of Toronto, Toronto, ONT MSS 3 H6, Canada \\ ${ }^{4}$ Advanced Chemical Technology Division, Korea Research Institute of Chemical Technology, Daejeon 305-600, Korea \\ Received Mav 25, 2006
}

Key Words : Zinc(II) complex, Crystal structure, Tetraazamacrocycle

Cyclam and its derivatives attract great interests due to their highly potent and selective anti-HIV activity by specifically blocking the co-receptor CXCR4 . $^{-5}$ Particularly, the xylyl-bicyclam known as AMD3100 has recently been on clinical trials for the treatment of AIDS. The aspartate residues (Asp 171 and Asp 262) having carboxylate groups of the CXCR4 co-receptor have been understood to participate in the recognition of cyclams. ${ }^{3,6}$ The antiviral activity is greatly enhanced by metal complexation, especially zinc(II) ion, to macrocycles. ${ }^{7.8}$ It is believed that the metal ions of the zinc(II) complexes preferentially recognize the aspartates of the CXCR4 co-receptor by coordination. Therefore, the better knowledge of interactions between zinc(II) macrocycles and carboxylates is crucial for the improved design and development of more effective antiHIV agents. In this context, we have made an effort to expand upon the examples of carboxylato zinc(II) macrocycles to elucidate the nature of interactions between zinc(II) macrocycles and carboxylates. Herein, we rejort the synthesis, structure and properties of a new carboxylato zinc(II) complex $\operatorname{Zn}(\mathbf{L})(\mathrm{apc})_{2} \quad$ (1) $\quad(\mathbf{L}=5,16$-dimethyl-2,6,13,17tetraazatricyclo $\left[16.4 .0^{1,18}, 0^{7,12}\right]$ docosane, apc $=3$-amino-2pyrazinecarboxylate) in which the macrocycle $\mathbf{L}$ has a close resemblance to a cyclam.<smiles>C1CNCCNCCNCCNC1</smiles>

Cyclam

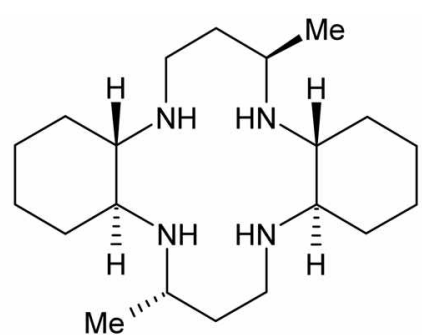

$\mathbf{L}$

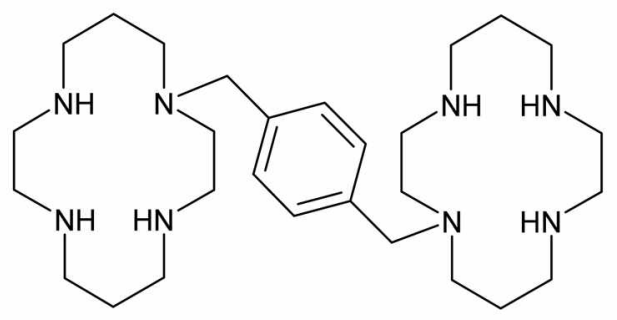

AMD 3100

\section{Experimental Section}

Materials, Methods and Apparatus. All chemicals used in the synthesis were of reagent grade and used without further purification. Distilled water was used for all procedures. Infrared spectra of solid samples were recorded on a Perkin-Elmer Paragon 1000 FT-IR spectrophotometer between $4000 \mathrm{~cm}^{-1}$ and $400 \mathrm{~cm}^{-1}$ as Nujol mulls on $\mathrm{KBr}$ discs. Thermal analysis (TGA-DTG) was performed on a Perkin-Elmer Model TGA-7 Thermogravimetric Analyzer under air from 50 to $800^{\circ} \mathrm{C}$ at a heating rate of $10^{\circ} \mathrm{C} / \mathrm{min}$. Elemental analysis was performed by the Korea Research Institute of Chemical Technology, Daejeon, Korea. The free ligand $\mathbf{L}$ was prepared according to a literature procedure. ${ }^{9}$ The precursor complex $\mathrm{Zn}(\mathbf{L})\left(\mathrm{NO}_{3}\right)_{2}$ was prepared by refluxing ligand $\mathbf{L}(3.36 \mathrm{~g}, 1.0 \mathrm{mmole})$ and $\mathrm{Zn}\left(\mathrm{NO}_{3}\right)_{2} \cdot 6 \mathrm{H}_{2} \mathrm{O}$ ( $3 \mathrm{~g}, 1.01 \mathrm{mmole}$ ) in stining methanol for a day, filtering the white powder, washing with methanol, and finally drying in air.

Preparation of 1. To a DMF solution of $\mathrm{Zn}(\mathbf{L})\left(\mathrm{NO}_{3}\right)_{2}$ (526 mg, $1.0 \mathrm{mmole}$ ) were added an aqueous solution of Hapc (278 mg, 2.0 mmole) and several drops of triethylamine. The mixture was allowed in an open beaker at room temperature. Colorless blocks of 1 were obtained in a week. Suitable crystals of 1 for X-ray diffraction studies and other measurements were manually collected under a microscope. Anal. Calcd. for $\mathrm{C}_{30} \mathrm{H}_{4 \times} \mathrm{ZnN}_{10} \mathrm{O}_{4}: \mathrm{C}, 53.08 ; \mathrm{H}, 7.08 ; \mathrm{N}$, 20.64. Found C, 52.95; H, 7.28; N, 20.51\%. IR (Nujol, $\left.\mathrm{cm}^{-1}\right)$ : $3227(v \mathrm{NH}), 3145(v \mathrm{NH}), 1587(v \mathrm{CO})$.

X-ray Crystallography. A summary of selected crystallographic data and selected interatomic distances and angles for 1 are given in Tables 1 and 2. X-ray data were collected on a Nonius Kappa CCD diffractometer, using graphite monochromated Mo $\mathrm{K}_{\alpha}$ radiation $(\lambda=0.71073 \AA)$. $\mathrm{A}$ combination of $1^{\circ} \phi$ and $\omega$ (with $\kappa$ offsets) scans were used to collect sufficient data. The data frames were integrated and scaled using the Denzo-SMN package. ${ }^{10}$ The structure was solved and refined using the SHELXTLMC V5.1 package. ${ }^{11}$ Refinement was performed by full-matrix least squares on $F^{2}$ using all data (negative intensities included). Hydrogen atoms were included in calculated positions, except for those involving in hydrogen bonding specifically for the hydrogen atoms bonded to the nitrogen atoms, which were refined with isotropic thermal parameters. 
Table 1. Crystal data and structure refinement for 1

\begin{tabular}{ll}
\hline Empirical formula & $\mathrm{C}_{30} \mathrm{H}_{48} \mathrm{ZnN}_{10} \mathrm{O}_{4}$ \\
Formula weight & 678.15 \\
Temperature (K) & $150(2)$ \\
Wavelength & $0.71073 \AA$ \\
Crystal system & Monoclinic \\
Space group & $\mathrm{P}_{1} / \mathrm{n}$ \\
Unit cell dimensions & $\mathrm{a}=8.4493(6) \AA$ \\
& $\mathrm{b}=17.2927(15) \AA$ \\
& $\mathrm{c}=10.9936(7) \AA$ \\
& $\beta=104.809(4)^{\circ}$ \\
Volume & $1552.9(7) \AA^{3}$ \\
7. & 2 \\
Density(calcd) & $1.450 \mathrm{Mg}^{3} \mathrm{~m}^{3}$ \\
Absorption coefficient & $0.845 \mathrm{~mm}^{-1}$ \\
Independent reflections & $3518[\mathrm{R}(\mathrm{int})=0.0801]$ \\
Goodness-of-fit on $\mathrm{F}^{2}$ & 1.028 \\
Final R indices [I>2 $\left.\mathrm{I}_{\mathrm{I}} \mathrm{I}\right]$ & $\mathrm{R}_{1}=0.0534, w \mathrm{R}_{2}=0.1225$ \\
$\mathrm{R}$ indices (all data) & $\mathrm{R}_{1}=0.1123, \mathrm{w} \mathrm{R}_{2}=0.1494$ \\
\hline
\end{tabular}

Table 2. Selected bond distances $(\AA)$ and angles $\left({ }^{\circ}\right)$ for 1

\begin{tabular}{llll}
\hline Zn1-N1 & $2.033(3)$ & $\mathrm{Zn1-N2}$ & $2.113(3)$ \\
$\mathrm{Zn} 1-\mathrm{N} 1 \# 1$ & $2.153(3)$ & $\mathrm{Zn} 1-\mathrm{N} 2 \# 1$ & $2.143(3)$ \\
$\mathrm{Zn} 1-\mathrm{O} 1$ & $2.099(2)$ & O1-C11 & $1.260(4)$ \\
$\mathrm{N} 1-\mathrm{Zn} 1-\mathrm{O} 1$ & $90.46(11)$ & $\mathrm{N} 1-\mathrm{Zn} 1-\mathrm{N} 2$ & $98.12(10)$ \\
O1-Zn1-N2 & $92.04(11)$ & $\mathrm{N} 1-\mathrm{Zn} 1-\mathrm{N} 2 \# 1$ & $83.96(10)$ \\
O1-Zn1-N2\#1 & $99.87(10)$ & $\mathrm{N} 2-\mathrm{Zn} 1-\mathrm{N} 2 \# 1$ & $167.91(4)$ \\
N1-Zn1-N1\#1 & $168.12(4)$ & O1-Zn1-N1\#1 & $101.42(11)$ \\
N2-Zn1-N1\#1 & $81.86(10)$ & N2\#1-Zn1-N1\#1 & $93.65(10)$ \\
\hline
\end{tabular}

Symmetry transformations used to generate equivalent atoms: $\# 1-\mathrm{x}+1$, $-y+1,-z^{+1}$

\section{Results and Discussion}

Structure. The structure of the discrete neutral complex 1 shows that the central zinc(II) ion is coordinated axially by two apc ligands as shown in Figure 1. The macrocyclic ligand skeleton in 1 takes the most stable "trans III" conformation as usual. The coordination environment around the central zinc(II) ion exhibits an octahedron with four $\mathrm{Zn}-\mathrm{N}$ and two $\mathrm{Zn}-\mathrm{O}$ bonds. The $\mathrm{Zn}$ atom does not lie exactly on the inversion center (sits ca. $0.22 \AA$ above the NI-N2-N1A$\mathrm{N} 2 \mathrm{~A}$ mean plane) and is disordered. The $\mathrm{Zn}-\mathrm{N}$ distances vary from $2.033(3) \AA$ to $2.113(3) \AA$ with an average distance of ca. $2.073 \AA$, which are comparable to those found in related complexes. ${ }^{2.12}$ The $\mathrm{Zn}-\mathrm{O}$ distance of $2.099(2) \AA$ lies in the lower limit of the previously reported values ([ $\mathrm{Zn}_{2}$ (xylyl-bicyclam) $\left.(\mathrm{OAc})_{2}\right](\mathrm{OAc})_{2} \cdot 2 \mathrm{CH}_{3} \mathrm{OH} ; \quad \mathrm{Zn}-\mathrm{O}=$ $2.089(2), 2.407(2) \AA,\{\mathrm{Zn}(\mathbf{L})$ (phthalate $)\}_{\mathrm{n}} \cdot\left(\mathrm{CH}_{3} \mathrm{OH}\right)_{2 \mathrm{n}} \cdot{ }^{2} \mathrm{Zn}-$ $\mathrm{O}=2.220(2), 2.190(2) \AA,\left\{\mathrm{Zn}(\mathbf{L})(\mathrm{tp}) \cdot \mathrm{H}_{2} \mathrm{O}\right\}_{\mathrm{n}} ;^{12} \mathrm{Zn}-\mathrm{O}=$ $2.1559(12) \AA,\left\{\mathrm{Zn}(\mathbf{L})\left(\mathrm{H}_{2} \text { bta }\right) \cdot 2 \mathrm{H}_{2} \mathrm{O}\right\}_{\mathrm{n}},{ }^{12} \mathrm{Zn}-\mathrm{O}=2.2839$ (14) $\AA, \mathrm{Zn}(\mathbf{L})\left(\mathrm{H}_{2} \mathrm{btc}\right)_{2} \cdot 2 \mathrm{DMF} ;{ }^{\prime 2} \mathrm{Zn}-\mathrm{O}=2.2222(12),\{[\mathrm{Zn}(\mathbf{L})-$ (maleate) $\left.{ }_{2} \cdot \mathrm{H}_{2} \mathrm{O}\right] \xi_{n},{ }^{13} \mathrm{Zn}-\mathrm{O}=2.1968(16), 2.2840$ (16); where tp $=$ terephthalate, $b t a=1,2,4,5$-benzenetetracarboxylate and btc $=1,3,5$-benzenetricarboxylate). The observed strong

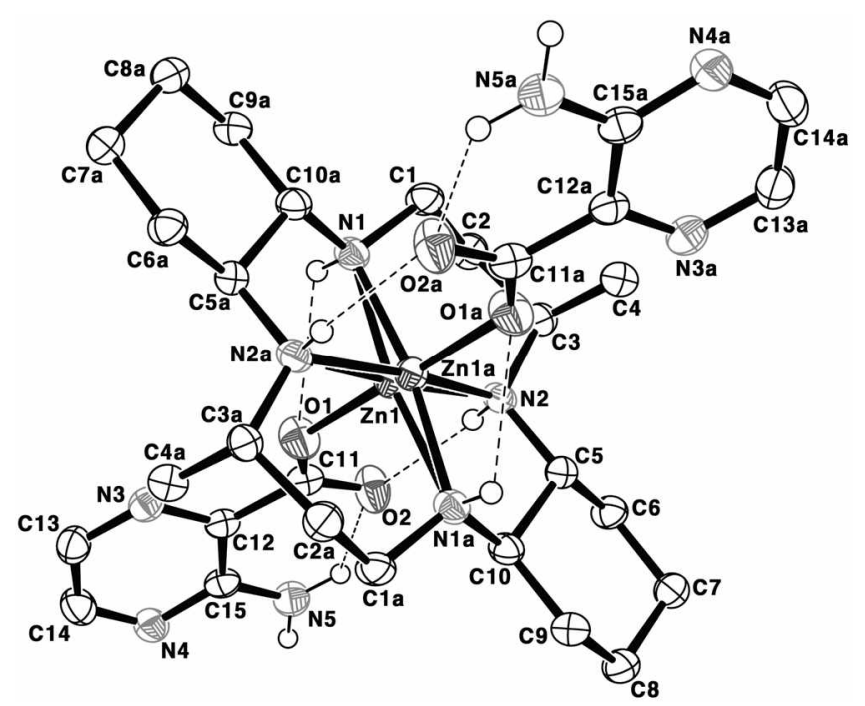

Figure 1. Molccular structure for 1 with atom-labeling schene. Hydrogen atoms other than those participating in hydrogen bonding are omitted for clarity.

interaction between the zinc(II) ion and carboxylates in $\mathbf{1}$ is supported by the concomitant presence of hydrogen bonding interactions between the $\mathrm{N}-\mathrm{H}$ groups of the macrocycle and oxygen atoms of the carboxylates. The pre-organization of $\mathrm{N}-\mathrm{H}$ groups of the zinc(II) macrocycle with its role in profacial selection of apc anion binding is achieved, ultimately resulting in the formation of one strong $\mathrm{Zn}$ coordination bond as well as two weaker hydrogen bonds (N1-HINA $\cdots \mathrm{OI}=2.934(3) \AA, \mathrm{N} 2-\mathrm{H} 2 \mathrm{NA} \cdots \mathrm{O} 2=2.982(4)$ $\AA)$. In an earlier report by Gerlach et $a l,{ }^{3}$ it has been raised that the acetate can make a strong coordination bond to the zinc(II) ion ( $\mathrm{Zn}-\mathrm{O}=1.96 \AA$ ) and one weaker hydrogen bond to a nitrogen in the cyclam system by optimized density functional methods (DFT).

Properties. Compound 1 was stable indefinitely in air, and the microanalytical and thermal analyses clearly supported the structure determined by X-ray diffraction studies. The IR spectra of 1 gave evidences for the presence of the macrocycle and apc ligands as described in Experimental Section. The TGA curve for 1 showed a first weight loss of $50.0 \%$ (calculated $49.5 \%$ ) over $290-335 \%$ with an endothemic processes centered at $320^{\circ} \mathrm{C}$, corresponding to the loss of the macrocycle. On further heating, gradual weight loss was observed in $335-645^{\circ} \mathrm{C}$ range with the loss of apc ligands. Finally, the $\mathrm{ZnO}$ residue (observed $11.5 \%$, calculated $12.0 \%$ ) was remained above $645^{\circ} \mathrm{C}$ (Figure 2).

In conclusion, we have prepared and fully characterized the new carboxylato zinc(II) complex 1. The carboxylate groups of the apc ligands in the complex 1 show strong coordination behavior towards the zinc(II) ion with hydrogen bonding interactions between the $\mathrm{N}-\mathrm{H}$ groups of the macrocycle and oxygen atoms of the apc ligands. From this account, we conclude that the coordination of carboxylate groups of apc ligands to the zinc(II) ion is reinforced by the presence of additional hydrogen bonding interactions between the macrocycle and carboxylates. Therefore, the 


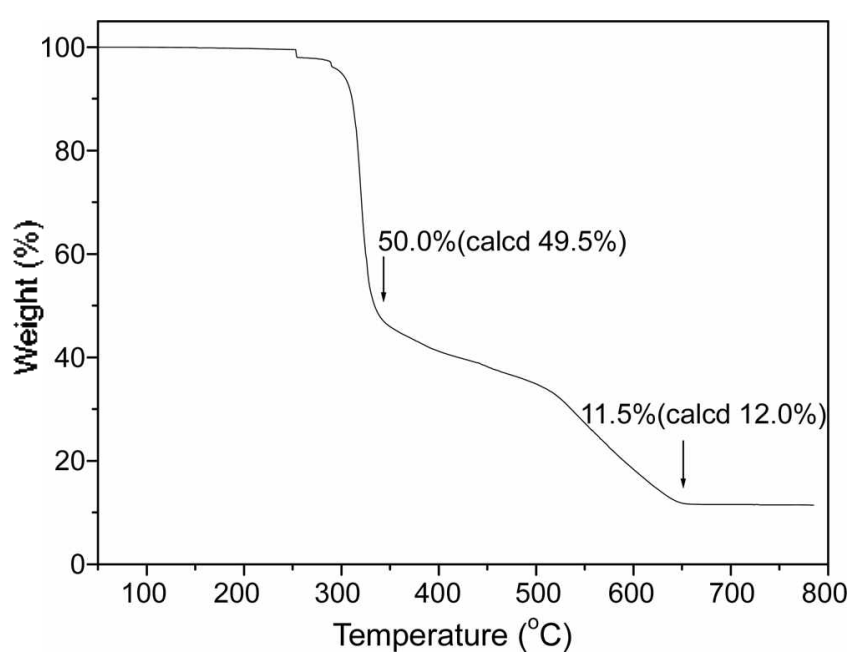

Figure 2. TGA curve for 1.

zinc(II) complex 1 could be a good model system for the understanding of the nature of molecular interactions between the zinc(II) macrocycle and carboxylates as well as the importance of the role of hydrogen bonding interactions in forming a strong coordination bond.

Supplementary Material. Crystallographic data for the structure reported here have been deposited with Cambridge Crystallographic Data Center (Deposition No. CCDC 607957). These data can be obtained free of charge via http: /www.ccdc.cam.ac.uk/conts/retrieving.html or from CCDC, 12 Union Road, Cambridge CB2 1EZ, UK, fax: 441223 336033, email: deposit@ccdc.cam.ac.uk.
Acknowledgments. This work was supported by Pukyong National University Research Foundation Grant in 2004.

\section{References}

I. Liang. X.; Parkinson, J. A.; Weishâupl, M.; Gould, R. O.; Paisey, S. J.; Park, H.-S.; Hunter, T. M.; Blindauer, C. A.; Parsons, S.; Sadler, P. J. J. Am. Chent. Soc. 2002, 124, 9105.

2. Liang, X.; Weishāupl, M.; Parkinson, J. A.; Parsons, S.; McGregor, P. A.; Sadler, P. J. Chem. Em: J, 2003, 9, 4709.

3. Gerlach, L. O.; Jakobsen, J. S.; Jensen, K. P.; Rosenkilde, M. R.; Skerli, R. T.; Ryde, U.; Bridger, G J.; Schwart, T. W. Biochemistry 2003, 42, 710.

4. Paisey, S. J.; Sadler, P. J. Chem. Conmum. 2004, 306.

5. Liang, X.; Sadler, P. J. Chem. Soc. Rev, 2004, 33, 246.

6. Gerlach, L. O.; Skerlj, R. T.; Bridger, Gi J.; Schwartz, T, W. $J$. Biol. Chem, 2001, 276, 14153.

7. Bridger, G J.; Skerlj, R. T.; Thornton, D.; Padmanabhan, S.; Martellucci, S. A.; Henson, G W.; Abrams, M. J.; Yamamoto, N.; De Vreese, K.; Pauwels, R.; De Clercq. E. J. Med. Chem. 1995, 38,366 .

8. Joao, H. C.; De Vreese, K.; Pauwels, R.; De Clercq, E.; Henson, G. W; Bridger, G J. Med. Chem, 1995, 38, 3865.

9. Kang, S.G.; Kweon, J. K.; Jung, S.-K. Bull, Korean Chem, Soc. $1991,12,483$.

10. Otwinowski, Z; Minor, W. In Methods in Enzymology: Macromolectilar Crystallograph; Part A; Carter, C. W., Sweet, R. M., Eds.; Academic Press: London, 1997; Vol. 276, pp 307326.

1 1. Sheldrick, G. M. SHEIXZ1PC V6.I Windows NT Version; Bulker Analytical X-ray Systems Inc.: Madison, WT, 2001.

12. Jo, H.; Lough, A. J.; Kim, J. C. Inorg. Chim. Acta 2005, 358 , 1274.

13. Kim, J. C.; Lough, A. J.; Park, H.; Kang, Y. C. Inorg. Chem. Commin, 2006, 9, 514 . 